\title{
UPAYA MENINGKATKAN PRESTASI BELAJAR MATEMATIKA MELALUI PEMBELAJARAN REALISTIK PADA SISWA KELAS V SDN 144/IX SOLOK MUARO JAMBI
}

\author{
Suhartini ${ }^{1}$ \\ Guru SDN 144/IX SOLOK Muaro Jambi ${ }^{1}$ \\ Email : hartini144@yahoo.com
}

\begin{abstract}
ABSTRAK
Pembelajaran akan memiliki arti jika guru dapat mendorong partisipasi siswa secara aktif. Hasil observasi memperlihatkan bahwa siswa belum berpartisipasi aktif dalam pembelajaran, kondisi ini berdampak pada prestasi belajar Matematika yang masih di bawah KKM. Tujuan dari penelitian ini untuk meningkatkan prestasi belajar Matematika melalui Pembelajaran Matematika Realistik pada siswa kelas V SDN 144/IX SOLOK Kecamatan Kumpeh Ulu Kabupaten Muaro Jambi. Penelitian tindakan kelas ini dilaksanakan dengan bekerjasama dengan guru kelas. Metode penelitian ini menggunakan variasi model Kemmis \& McTaggart dalam siklus yang terdiri dari perencanaan, pelaksanaan, pengamatan, dan refleksi. Subjek dalam penelitian adalah siswa kelas V yang berjumlah 37 siswa. Objek penelitian adalah prestasi belajar Matematika melalui Pembelajaran Matematika Realistik. Teknik pengumpulan data adalah tes dan observasi. Analisa data dalam penelitian ini menggunakan teknik analisa deskriptif kuantitatif dan kualitatif. Hasil penelitian menunjukkan dengan diterapkannya Pembelajaran Matematika Realistik pada proses pembelajaran matematika dalam materi operasi hitung bilangan bulat dapat meningkatkan kualitas proses dan hasil belajar matematika. Mutu suatu proses pembelajaran dapat diukur dengan peningkatan persentase partisipasi siswa dari siklus I sebesar 74,39\% menjadi 88,56\% pada siklus II. Hasil belajar matematika menunjukkan peningkatan dari dari pra tindakan sebanyak 8 siswa (21,62\%) telah mencapai KKM menjadi 19 siswa (51,35\%) pada siklus I dan 32 siswa (86,5\%) pada siklus II.
\end{abstract}

Kata Kunci:

Hasil Belajar; Matematika; Matematika Realistik; Pembelajaran

\begin{abstract}
Learning will be meaningful if the teacher involves the students directly in the learning process. The observation showed that the teacher had not involved the students yet directly in the learning process so mathematic achievement result of students is still low. This research aims to increase students's mathematic learning achievement with realistic mathematic learning for fifth grade class of SD N Kumpeh Ulu 1 Kecamatan Kumpeh Ulu Kabupaten Muaro Jambi. This research was a kind of classroom action research which was collaborated with the teacher. This research design used modified Kemmis \& McTaggart model in 2 cycles consisting of planning, action, observation, and reflection. The subject of the research were 37 fifth grade students. The object of the research is mathematic achievement result with realistic mathematic learning. Data collecting techniques were test and observation. Data analysis techniques were quantitative description and qualitative description. The research showes that applying realistic mathematic learning in mathematic learning process of arithmetic operation material can improve process quality and mathematic learning achievement. Learning quality process was reflected on the improvement of students' participation percentage in the first cycle from $74,39 \%$ to $88,56 \%$ in the second cycle. The improvement of mathematic learning achievement can be found in pre action step showing 8 students $(21,62 \%)$ had achieved minimum mastery criteria then it become 19 students $(51,35 \%)$ in the first cycle and 32 students $(86,5 \%)$ in the second cycle.
\end{abstract}

Keywords:

learning achievement; mathematic; realistic mathematic; learning 


\section{PENDAHULUAN}

Pendidikan

di Indonesia

dilaksanakan secara formal dan non formal. Secara formal pendidikan dibagi menjadi empat jenjang terdiri dari jenjang pendidikan anak usia dini, jenjang pendidikan dasar, jenjang pendidikan menengah dan jenjang pendidikan tinggi. Jenjang pendidikan dasar merupakan jenjang yang strategis dan prioritas dalam meningkatkan kualitas sumber daya manusia (SDM). Sekolah Dasar adalah salah satu jenjang yang menyelenggarakan proses pendidikan harus dikembangkan menurut potensi siswa baik pada aspek kognitif, afektif dan psikomotorik secara optimal guna menghadapi tuntutan pendidikan dan guna meningkatkan kualitas sumber daya manusia (SDM).

Guru mendapatkan peran yang utama dalam melaksanakan proses belajar mengajar. Guru berperan dalam setiap proses pembelajaran. Keberhasilan proses pembelajaran akan ditentukan oleh seberapa besar guru dapat berpartisipasi aktif dan berinovasi dalam srategi dan teknik pembelajaran. Guru harus mampu menyampaikan konsep-konsep yang abstrak dengan benda atau objek yang konkret agar mudah dipahami oleh siswa.

Matematika merupakan mata pelajaran pokok yang diajarkan di jenjang Sekolah Dasar. Mata pelajaran matematika merupakan mata pelajaran pokok pada jenjang pendidikan dasar mempunyai peran strategis dalam pembangunan IPTEK karena mempelajari matematika sama halnya melatih pola inovatif dalam memecahkan masalah yang dihadapi dalam kehidupan sehari-hari. Matematika juga mempunyai peranan dalam melatih penalaran siswa.

Kegunaan matematika dikemukakan oleh Subarinah (2006), bahwa matematika sangat berguna bagi siswa SD adalah sesuatu yang konkret yang tidak perlu dipermasalahkan lagi, terlebih pada era pengembangan ilmu pengetahuan dan teknologi dewasa ini.

Matematika merupakan mata pelajaran yang sulit dipahami, oleh karena itu penguasaan terhadap matematika harus diperlukan dan konsep-konsep matematika harus dipahami dengan betul dan benar sejak dini. Suatu konsep disusun berdasarkan konsep-konsep sebelumnya dan akan menjadi dasar bagi konsepkonsep selanjutnya, sehingga pemahaman yang salah dari suatu konsep akan berakibat pada kesalahan pemahaman terhadap konsep-konsep lanjutannya (Prihandoko, 2006).

Siswa SD sering menganggap bahwa matematika merupakan mata pelajaran yang membosankan dan tidak menarik. Hal ini disebabkan karena model maupun metode pembelajaran yang digunakan guru dalam mengajar kurang dapat membangkitkan minat belajar siswa, sehingga hasil belajar yang didapatkan kurang maksimal. Terkait hal ini Suharjo (2006), mengemukakan bahwa pembelajaran pada hakikatnya tidak hanya sekedar menyampaikan pesan pembelajaran kepada peserta didik, akan tetapi merupakan dasar mengajar secara terpadu, serta menciptakan sistem lingkungan yang mendukung peserta didik dapat melaksanakan proses pembelajaran secara efektif dan efisien.

Hal ini sejalan dengan pendapat Sanjaya (2011) mengungkapkan ada beberapa faktor yang mempengaruhi keberhasilan belajar siswa di antaranya adalah guru, siswa, sarana dan prasarana, serta lingkungan.

Pembelajaran bukan hanya menyampaikan informasi materi agar dikuasai oleh siswa, tetapi memberikan dukungan agar siswa mengusahakan terjadinya proses belajar dalam dirinya. Hasil belajar adalah perubahan pada diri 
anak meliputi kemampuan intelektual, sikap/minat maupun keterampilan setelah mengikuti proses belajar mengajar. Hasil belajar dapat diukur dengan melaksanakan Tes Kemampuan Intelektual. Siswa dikatakan berprestasi apabila telah mencapai Kriteria Ketuntasan Minimal (KKM) yang telah ditentukan pada mata pelajaran Matematika.

Sejalan dengan pendapat Sudjana (2006) mendefinisikan hasil belajar adalah kemampuan yang dimiliki siswa setelah menerima pengalaman belajarnya. Sejalan dengan pendapat tersebut, Widoyoko (2009) mengemukakan bahwa hasil dari kegiatan pembelajaran adalah perubahan yang terjadi pada diri siswa bersifat non fisik seperti perubahan sikap, pengetahuan maupun kecakapan. Perubahan yang terjadi pada diri siswa dibedakan menjadi dua yaitu output dan outcome. Perubahan tersebut dinilai dalam bentuk angka dan kalimat.

Selanjutnya Bloom dalam (Sudjana, 2006) mengklasifikasikan hasil belajar menjadi tiga ranah, yaitu (1) ranah kognitif, (2) ranah afektif, dan (3) ranah psikomotoris.

Berdasarkan observasi di Kelas V pada mata pelajaran matematika menunjukkan bahwa guru menyampaikan materi dengan metode ceramah tanpa melibatkan keaktifan siswa di dalam proses pembelajaran. Guru juga tidak menggunakan alat peraga untuk menyampaikan materi pembelajaran dan bahkan guru tidak mengkaitkan materi dengan lingkungan siswa, sehingga konsep pembelajaran yang sedang diajarkan benarbenar abstrak. Metode seperti ini terkesan kurang efektif, karena siswa hanya sekedar mendengarkan penjelaskan dari guru tanpa pernah menemukan dan memahami sendiri tentang konsep yang sedang diajarkan. Proses pembelajaran seperti itu membuat siswa mudah lupa dengan materi karena terkesan hanya menghafalkan saja.

Menurut Anderson (2015) pembelajaran konstruktif dipandang sebagai tujuan yang penting. Proses-proses kognitif menjadi alat untuk mendeskripsikan aktivitas-aktivitas kognitif siswa dalam pembelajaran konstruktif. Kategori-kategori dalam dimensi proses kognitif itu ialah : (a) Mengingat; (b) Memahami, Mengaplikasikan, (d) Menganalisis, (e) Mengevaluasi dan (f) Mencipta.

Berdasarkan hasil wawancara dengan wali kelas 5 di pada mata pelajaran matematika nilai rata-rata siswa paling rendah dibandingkan dengan mata pelajaran yang lain. Berdasarkan daftar nilai siswa kelas 5 tahun ajaran 2019/2020 semester 1 bahwa nilai rata-rata matematika materi operasi hitung bilangan bulat masih rendah. Siswa kelas 5 masih kesulitan memahami materi operasi hitung bilangan bulat dengan kompetensi dasar melakukan operasi hitung campuran bilangan bulat. Kesulitan ini diketahui dari hasil ulangan harian matematika siswa kelas 5 pada operasi hitung campuran bilangan bulat, dari 37 siswa, ada 15 siswa yang nilainya tidak mencapai KKM dengan rentang nilai 40-64, 10 siswa yang dapat melebihi KKM dengan rentang nilai 70-100, dan 12 lainnya hanya mencapai KKM dengan rentang nilai 65-70. Guru kelas 5 menentukan nilai kriteria ketuntasan minimal (KKM) adalah 65.

Pendekatan yang dapat diterapkan dalam pembelajaran matematika adalah Pembelajaran Matematika Realistik. Hal ini didukung oleh pendapat Tarigan (2006) bahwa proses pembelajaran matematika realistik fokus pada pentingnya konteks nyata yang dikenal siswa dan proses konstruksi pengetahuan matematika oleh siswa sendiri. Pembelajaran matematika realistik 
merupakan pendekatan yang lebih fokus pada aktivitas siswa untuk mencari, menemukan dan membangun sendiri pengetahuan yang dia perlukan sehingga pembelajaran menjadi terpusat pada siswa.

Berdasarkan latar belakang masalah di atas, maka dapat diidentifikasi masalah sebagai berikut: (1) Rendahnya hasil belajar matematika yang ditunjukkan dengan nilai ulangan harian tahun ajaran 2019/2020. (2) Pembelajaran yang berlangsung masih menggunakan metode ceramah.(3) Pembelajaran masih cenderung besifat abstrak. (4) Siswa masih kurang aktif dalam pembelajaran Matematika. (5) Guru belum mengaitkan pembelajaran dengan apa yang ada di kehidupan nyata atau ada di lingkungan siswa.

$\begin{array}{ccc}\begin{array}{c}\text { Penelitian } \\ \text { permasalahan dibatasi pada }\end{array} & \text { peningkatan proses }\end{array}$
pembelajaran dan hasil belajar Matematika melalui pengkaitan pembelajaran dengan apa yang ada di kehidupan nyata dan lingkungan siswa. Berdasarkan batasan masalah di atas, maka peneliti dapat merumuskan permasalahan ini adalah "Bagaimana meningkatkan hasil belajar Matematika pada siswa kelas 5 , melalui Pembelajaran Matematika Realistik”,

Tujuan penelitian ini adalah untuk meningkatkan hasil belajar Matematika kelas 5 melalui Pembelajaran Matematika Realistik. Manfaat penelitian yang dapat diperoleh dari penelitian ini bagi siswa dapat meningkatkan wawasan dan pengetahuan siswa dalam pembelajaran matematika realistik, dan meningkatkan minat dan motivasi siswa dalam proses kegiatan pembelajaran. Manfaat bagi Guru adalah dapat memperkaya khasanah model dan metode dalam kegiatan pembelajaran dan mengembangkan keterampilan guru kelas khususnya, dalam menerapkan model pembelajaran matematika realistik untuk meningkatkan prestasi belajar siswa.
Jurnal Pendidikan Matematika Volume 4 Nomor 2 Tahun 2020

\section{METODE PENELITIAN}

Jenis penelitian ini adalah Penelitian Tindakan Kelas (PTK). Penelitian Tindakan Kelas merupakan suatu pengamatan terhadap kegiatan belajar berupa sebuah tindakan yang sengaja dilaksanakan dan terjadi dalam sebuah kelas secara bersama (Arikunto, 2007). Penelitian ini menggunakan model Kemmis \& Mc. Taggart (Madya, 2009) yang setiap siklus terdiri dari empat komponen tindakan yaitu perencanaan, pelaksanaan tindakan, observasi dan refleksi dalam suatu spiral yang saling terkait.

Penelitian ini dilaksanakan di SDN 144/IX Desa Solok Kecamatan Kumpeh Ulu Kabupaten Muaro Jambi Provinsi Jambi. Dalam penelitian ini dilakukan pengambilan data pada semester gasal tahun ajaran 2019/2020. Subjek penelitian ini adalah siswa kelas $\mathrm{V}$ tahun pelajaran 2019/2020 yang berjumlah 37 siswa terdiri dari 16 siswa laki-laki dan 21 siswa perempuan. Objek penelitian ini adalah hasil belajar yang diperoleh siswa kelas V , menggunakan Pembelajaran Matematika Realistik.

Pengumpulan data merupakan langkah yang paling utama dalam penelitian, adapun teknik pengumpulan data yang digunakan dalam penelitian ini adalah: (1) Tes digunakan untuk mengetahui peningkatan hasil belajar matematika siswa kelas V. (2) Observasi digunakan untuk mengumpulkan data proses pembelajaran. Aktivitas yang diobservasi dalam penelitian ini adalah ( a) bagaimana aktivitas guru dalam membelajarkan materi pelajaran kepada siswa, dan (b) bagaimana aktivitas siswa selama mengikuti pelajaran.

Dokumentasi berupa foto-foto yang memberikan gambaran konkret mengenai aktivitas siswa selama proses pembelajaran dan data berupa dokumendokumen seperti 
$\pi$ (Phi)

RPP dan LKS. (Sugiyono 2012)

Analisa data yang digunakan dalam penelitian adalah analisa deskriptif kuantitatif dan kualitatif. Analisa deskriptif kuantitatif digunakan untuk menganalisis data yang berupa angka-angka untuk menganalisis hasil tes, sedangkan deskriptif kualitatif digunakan untuk menganalisis data yang berupa kata-kata atau informasi yang berbentuk kalimat pada lembar observasi. Hal ini didukung oleh Arikunto (2006: 239) menjelaskan bahwa analisis data penelitian ada dua macam yaitu analisis data deskriptif kuantitatif dan deskriptif kualitatif.

\section{HASIL DAN PEMBAHASAN Hasil Penelitian}

Penelitian Tindakan Kelas ini dilaksanakan dalam 2 siklus, hasil penelitian pada setiap tahapan siklus dideskripsikan sebagai berikut:

\section{Siklus I}

\section{Siklus I Pertemuan 1}

Pertemuan pertama pada siklus I yang dideskripsikan sebagai berikut: (a) Kegiatan Awal. Guru menjelaskan .langkah-langkah pembelajaran yang akan dilakukan siswa dalam Pembelajaran Matematika Realistik.

Kegiatan Inti, guru membagi siswa menjadi 5 kelompok yang masing-masing kelompok terdiri dari 7-8 siswa. Pada tahapan penggunaan konteks guru memberikan masalah kontekstual yang berkaitan dengan operasi hitung campuran bilangan bulat dengan mengarahkan siswa untuk memahami perbedaan suhu di dalam dan di luar kulkas.

Hasil yang telah diperoleh pada tahap Siklus I yaitu tentang menentukan jenis bilangan bulat dengan garis bilangan adalah setiap angka yang ada di sebelah kanan angka 0 (nol) adalah bilangan bulat positif, sedangkan setiap angka yang ada di

sebelah kiri angka 0 (nol) adalah bilangan bulat negatif. Tahap matematisasi vertikal, guru bersama siswa mendapatkan hasil bahwa bilangan bulat terdiri dari bilangan bulat positif, bilangan bulat negatif, dan bilangan bulat nol. Tahap keterkaitan, guru mengaitkan materi jenis bilangan bulat dengan garis bilangan.

Kegiatan Akhir, Pada kegiatan akhir siswa dengan bimbingan guru menyimpulkan materi yang telah dipelajari yaitu menentukan jenis bilangan bulat dengan garis bilangan. Guru mengakhiri proses pembelajaran dengan memberikan motivasi agar siswa mau mempelajari materi dan mengerjakan soal-soal dalam buku pegangan siswa.

\section{Siklus I Pertemuan 2}

Pertemuan kedua pada siklus I ini, pembelajaran Matematika pada pertemuan kedua membahas tentang Melakukan operasi penjumlahan dan pengurangan bilangan bulat. Pembelajaran Matematika Realistik dideskripsikan sebagai berikut: Kegiatan Awal, Guru menyampaikan tujuan pembelajaran yang akan dicapai siswa yaitu melakukan operasi penjumlahan dan pengurangan bilangan bulat. Guru menjelaskan langkah-langkah pembelajaran yang akan dilakukan siswa dengan Pembelajaran Matematika Realistik.

Kegiatan Inti, pada tahapan matematisasi horizontal guru mengeluarkan bebarapa buah kancing hitam dan putih, kemudian menjelaskan kepada siswa bahwa kancing baju putih melambangkan bilangan bulat positif sedangkan kancing baju hitam melambangkan bilangan bulat negatif. Pada tahapan interaktivitas guru membagi siswa menjadi 5 kelompok yang terdiri dari 7-8 siswa dan membagikan LKS kepada masing-masing kelompok untuk digunakan selama proses pembelajaran. Pada tahapan 


\section{$\pi$ (Phi)}

matematisasi vertikal guru bersama siswa mendapatkan suatu pemahaman tentang bagaimana suatu hasil operasi bilangan bulat itu bisa bernilai bilangan positif ataupun negatif sesuai dengan langkahlangkahnya. Kegiatan Akhir, pada kegiatan akhir guru menutup pembelajaran dengan memberikan motivasi agar siswa mau mempelajari materi yang ada dalam buku pegangan siswa.

\section{Siklus I pertemuan 3}

Kegiatan Awal, Guru mengingatkan siswa mengenai materi sebelumnya, setelah guru menyampaikan tujuan pembelajaran, guru menyampaikan bahwa hari itu setelah kegiatan pembelajaran dilakukan, akan diadakan evaluasi untuk menilai hasil belajar siswa.

Kegiatan Inti, Guru membagikan LKS kepada semua siswa yang akan digunakan dalam pembelajaran namun secara individu. Setiap siswa diberi penekanan apabila ada yang kurang bisa memahami soal, untuk menanyakan kepada guru dan guru akan menjelaskan kepada siswa. Kegiatan Akhir. Guru membagikan soal evaluasi siklus 1 dan semua siswa mengerjakan secara individu.

Tahap ketiga dari penelitian tindakan kelas ini adalah melakukan pengamatan (observasi). Adapun secara rinci hasil pengamatan pada siklus pertama adalah sebagai berikut: Observasi yang dilakukan pada siklus I meliputi dua pertemuan dari tiga pertemuan selama siklus I karena di pertemuan terahir hanya dilakukan evaluasi.

Dari kedua pertemuan tersebut, guru telah melakukan semua aktivitas yang ada dalam lembar observasi. Hasil observasi menunjukkan bahwa guru baru memberikan $71,87 \%$ atau pada kategori cukup untuk kegiatan pembelajaran kepada siswa yang disesuaikan dengan lembar observasi.

Hasil pembelajaran pada siklus I ini diperoleh pada pertemuan ketiga. Sebanyak 19 siswa dari 37 siswa dinyatakan tuntas, sedangkan jumlah siswa yang belum tuntas adalah 18 siswa. Ratarata hasil tes tersebut adalah 64,43. Berikut ini disajikan tabel hasil belajar siswa pada siklus I:

Tabel 1. Persentase Jumlah Siswa yang Tuntas Belajar pada Siklus I

\begin{tabular}{lcccc}
\hline \multirow{2}{*}{ Kategori } & \multicolumn{2}{c}{ Pra tindakan } & \multicolumn{2}{c}{ Siklus I } \\
\cline { 2 - 5 } & Siswa & $\mathbf{\%}$ & Siswa & $\mathbf{\%}$ \\
\hline Tuntas & 8 & 21,62 & 19 & 51,35 \\
Belum tuntas & 29 & 78,38 & 18 & 48,65 \\
Jumlah & 37 & 100 & 37 & 100 \\
\hline
\end{tabular}

Sumber : Hasil Olahan Data

Berdasarkan tabel di atas dapat diketahui sebanyak 19 siswa atau 51,35\% siswa dari seluruh siswa mendapatkan nilai $\geq 65$ dibandingkan data nilai pra tindakan yang hanya 8 siswa atau 21,62 \%, sedangkan jumlah siswa yang belum tuntas adalah 18 siswa atau 48,65\% siswa dari seluruh siswa mendapatkan nilai $<65$. Berdasarkan hasil tersebut dapat dikatakan terjadi peningkatan 29,73\% jumlah siswa yang tuntas belajar dilaksanakan pada siklus I. Hasil belajar pada pra tindakan dan Siklus I diperjelas pada diagram batang sebagai berikut. 


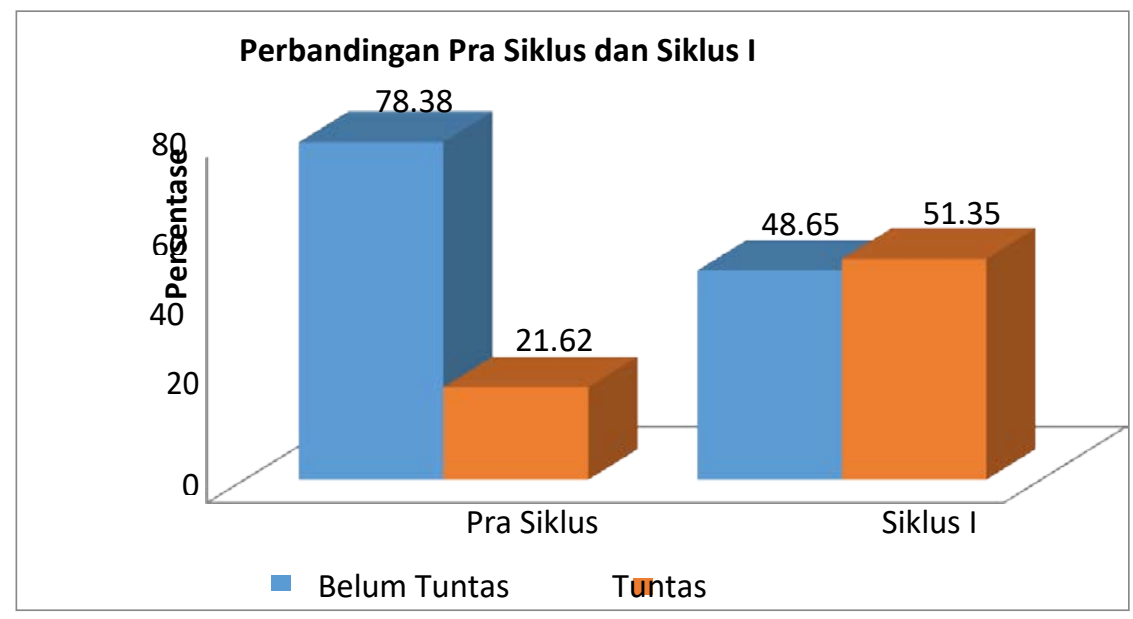

Gambar 1. Perbandingan hasil belajar pra tindakan dengan Siklus I

Hasil belajar Afektif berupa Partisipasi Siswa. Hasil observasi partisipasi siswa pada mata pelajaran Matematika siklus I untuk setiap pertemuan dan hasil observasi partisipasi siswa pada siklus I dapat dilihat pada tabel dan gambar berikut ini :

Tabel 2. Hasil Observasi Partisipasi Siswa Siklus I

\begin{tabular}{lcc}
\hline \multicolumn{1}{c}{ Aspek Pengamatan } & \multicolumn{2}{c}{ Pertemuan } \\
\hline Perhatian siswa terhadap pelajaran & I & II \\
Partisipasi dalam kelompok & 2,2 & 3,4 \\
Kemampuan berkomunikasi & 2,5 & 2,8 \\
Keberanian mengemukakan pendapat & 2,5 & 3 \\
Ketrampilan menggunakan alat/media & 3,4 & 3,5 \\
Tekun dalam bekerja & 3 & 3,2 \\
Menggunakan waktu dengan efektif & 2,8 & 3 \\
Mampu bekerja sama & 3 & 3,1 \\
\multicolumn{1}{c}{ Rerata } & 2,9 & 3,1 \\
\hline
\end{tabular}

Sumber: Hasil Olahan Data

Tabel 3. Partisipasi Siswa Siklus I

\begin{tabular}{lcc}
\hline & Pertemuan I & Pertemuan II \\
\hline Jumlah Skor & 849 & 919 \\
Rerata & 22,95 & 24,84 \\
Skor Tertinggi & 26 & 28 \\
Skor Terendah & 20 & 20 \\
\hline
\end{tabular}

Sumber: Hasil Olahan Data 


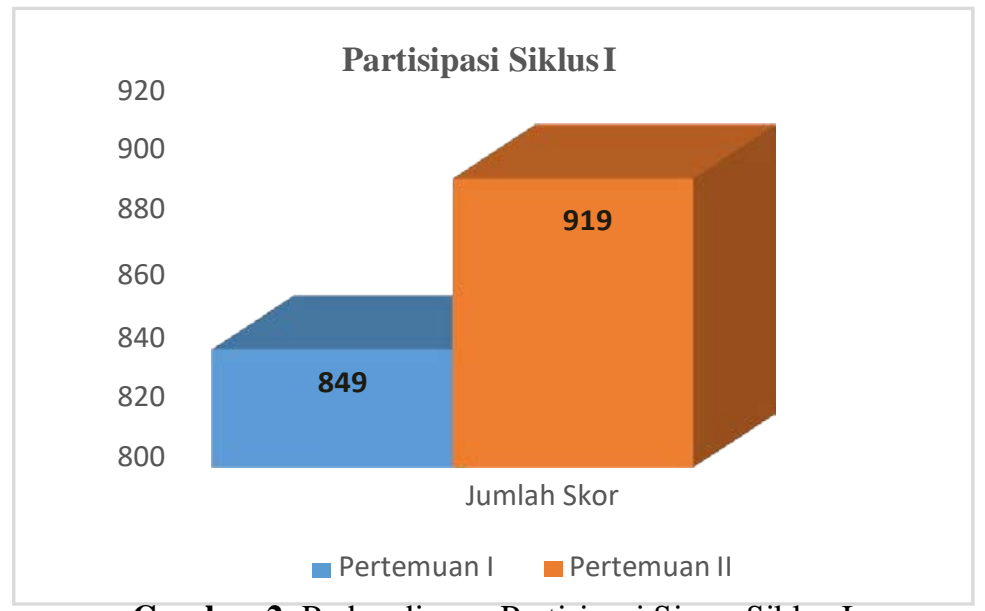

Gambar 2. Perbandingan Partisipasi Siswa Siklus I

Berdasarkan tabel hasil observasi partisipasi siswa siklus I di atas, dapat dilihat bahwa dari aspek partisipasi siswa diperoleh data dengan rerata 3 maka dapat dikatakan partisipasi siswa menunjukkan pada sering berpartisipasi dalam kegiatan pembelajaran.

\section{Refleksi (Reflecting)}

Kegiatan refleksi ditujukan sebagai bahan masukan pada tahap perencanaan siklus selanjutnya. Refleksi pada siklus I dilakukan oleh peneliti dan guru kelas V. Adapun hasil refleksi yang diperoleh pada siklus I dapat dilihat pada uraian di bawah ini : (a) Sebagian besar siswa kurang aktif. (b) Guru belum membimbing semua kelompok secara maksimal. (c) Siswa belum maksimal dalam memberikan tanggapan dan menarik kesimpulan.

Berdasarkan refleksi pelaksaan tindakan untuk siklus I, perlu dilaksanakan tindakan untuk siklus II. Hasil refleksi siklus I digunakan sebagai acuan untuk pelaksanaan tindakan pada siklus II.

\section{Siklus II}

\section{Perencanaan (Planning)}

Perencanaan siklus II dibuat berdasarkan garis besar hasil refleksi dari siklus I yang telah dijabarkan di atas..

Pelaksanaan tindakan siklus II dalam penelitian ini dilakukan sebanyak tiga kali pertemuan yang dideskripsikan sebagai berikut:

\section{Siklus II Pertemuan 1}

Pembelajaran Matematika pada pertemuan pertama membahas tentang pengukuran dalam pembelajaran Matematika melalui Pembelajaran Matematika Realistik sama halnya tahapan ada siklus I terdiri dari: Kegiatan Awal, Guru mengkondisikan siswa untuk menerima pelajaran dengan melakukan apersepsi dengan bertanya pada siswa (tahapan penggunaan konteks). Kegiatan Inti, Guru menulis sebuah operasi hitung perkalian di papan tulis, kemudian guru menjelaskan bahwa operasi perkalian itu adalah sebuah operasi penjumlahan yang berulang. Guru menjelaskan konsep dengan memberikan contoh yang akrab dengan kehidupan sehari-hari. Hasil yang telah diperoleh pada siklus II yaitu tentang melakukan operasi hitung perkalian bilangan bulat adalah, operasi perkalian merupakan sebuah operasi penjumlahan yang berulang, dan juga rumus untuk hasil operasi hitung perkalian. Kegiatan Akhir, 
$\pi$ (Phi)

pada kegiatan akhir siswa dengan bimbingan guru menyimpulkan materi yang telah dipelajari yaitu melakukan operasi hitung perkalian bilangan bulat. Guru menutup pembelajaran dengan memberikan motivasi agar siswa mau mempelajari materi dan mengerjakan soalsoal dalam buku pegangan siswa.

\section{Siklus II pertemuan 2}

Pertemuan kedua pada siklus II ini dilaksanakan sesuai jadwal mata pelajaran Matematika kelas VI. Pembelajaran Matematika pada pertemuan kedua membahas tentang menentukan kecepatan debit air dalam satuan jam/menit. Pembelajaran Matematika melalui Pembelajaran Matematika Realistik dilaksanakan sama dengan tahapan pada Siklus II pertemuan 1 yang terdiri dari Kegiatan Awal, Kegiatan Inti yang terdiri atas tahap matematisasi horizontal, tahap interaktivitas, dan tahap matematisasi vertikal dan Kegiatan Akhir, pada kegiatan akhir siswa dengan bimbingan guru menyimpulkan materi yang telah dipelajari.

\section{Siklus II Pertemuan 3}

Pertemuan ketiga pada siklus II ini dilaksanakan untuk pembelajaran matematika membahas tentang menentukan kecepatan debit air dalam satuan jam/menit. Pembelajaran Matematika melalui Pembelajaran Matematika Realistik dideskripsikan sama seperti pada siklus I dimulai dengan kegiatan awal, kegiatan inti dan kegiatan akhir.

Observasi yang dilakukan pada siklus II meliputi dua pertemuan dari tiga pertemuan selama siklus II karena di pertemuan terahir hanya dilakukan evaluasi. Dari kedua pertemuan tersebut, guru telah melakukan semua aktivitas yang ada dalam lembar observasi. Pertemuan pertama adalah materi operasi hitung perkalian bilangan bulat. Pada kegiatan awal, guru mengawali pembelajaran dengan memancing pengetahuan siswa terhadap perkalian dengan mengkaitkan pada kegiatan di sekitar siswa. Pertemuan kedua adalah materi operasi hitung pembagian bilangan bulat. Guru mengawali pembelajaran dengan memberikan masalah kontekstual yang berkaitan dengan materi pembagian.

Berdasarkan observasi kegiatan guru dalam pembelajaran menunjukkan bahwa guru sudah memberikan seluruh aspek kegiatan pembelajaran. Hasil observasi menunjukkan bahwa guru baru memberikan $93,75 \%$ atau dalam kategori sangat baik untuk kegiatan pembelajaran kepada siswa yang disesuaikan dengan lembar observasi. Guru telah memperbaiki cara mengajar yang disesuaikan dengan kebutuhannya.

Selain hasil observasi yang berupa aktivitas guru, peneliti juga memaparkan hasil belajar kognitif dan afektif siswa yang telah diperoleh pada siklus II sebagai berikut:

\section{(a) Hasil Belajar Kognitif.}

Hasil belajar pada siklus II ini diperoleh pada pertemuan ketiga. Sebanyak 32 siswa dari 37 siswa kelas V dinyatakan tuntas, sedangkan jumlah siswa yang belum tuntas adalah 5 siswa. Rata-rata hasil tes tersebut adalah 72,29. Persentase hasil belajar pada siklus II dapat dilihat pada tabel sebagai berikut. 
Tabel 4. Persentase jumlah siswa yang tuntas belajar pada siklus II

\begin{tabular}{ccccc}
\hline Kategori & \multicolumn{2}{c}{ Siklus I } & \multicolumn{2}{c}{ Siklus II } \\
& Siswa & $\%$ & Siswa & $\%$ \\
\hline Tuntas & 19 & 51,35 & 32 & 86,49 \\
Belum tuntas & 18 & 48,65 & 5 & 13,51 \\
Jumlah & 37 & 100 & 37 & 100 \\
\hline
\end{tabular}

Berdasarkan tabel di atas dapat diketahui bahwa pada siklus II sebanyak 32 siswa atau $86,49 \%$ siswa dari seluruh siswa mendapatkan nilai $\geq 65$

Berdasarkan hasil tersebut dapat dikatakan terjadi peningkatan 35,14\% jumlah siswa yang tuntas belajar dilaksanakan pada siklus II. Perbandingan hasil belajar pada Siklus I dan Siklus II diperjelas pada diagram batang sebagai berikut: dibandingkan data nilai siklus I yang hanya 19 siswa atau 51,35\%, sedangkan jumlah siswa yang belum tuntas adalah 5 siswa atau $13,51 \%$ siswa.

(b).Hasil belajar Afektif Partisipasi Siswa. Hasil observasi partisipasi siswa pada mata pelajaran Matematika siklus II untuk setiap pertemuan dapat dilihat pada tabel hasil observasi partisipasi siswa pada siklus II. Berikut ini tabel hasil observasi partisipasi siswa pada siklus II.

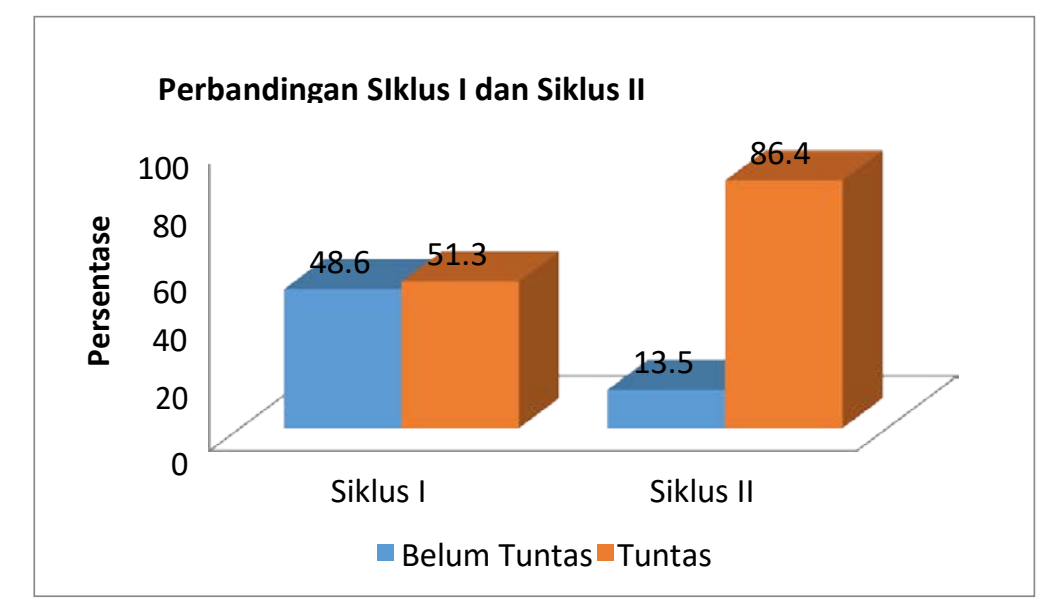

Gambar 3. Perbandingan hasil belajar siklus I dengan Siklus II

Tabel 5. Partisipasi Siswa Siklus II

\begin{tabular}{lcc}
\hline & Pertemuan I & Pertemuan II \\
\hline Jumlah Skor & 1029 & 1068 \\
Rerata & 27,81 & 28,86 \\
Skor Tertinggi & 31 & 31 \\
Skor Terendah & 25 & 25 \\
\hline
\end{tabular}


Tabel 6. Hasil Observasi Partisipasi Siswa Siklus II

\begin{tabular}{lcc}
\hline \multicolumn{1}{c}{ Aspek Pengamatan } & \multicolumn{2}{c}{ Pertemuan } \\
& I & II \\
\hline Perhatian siswa terhadap pelajaran & 3,6 & 3,7 \\
Partisipasi dalam kelompok & 3 & 3,4 \\
Kemampuan berkomunikasi & 3,4 & 3,6 \\
Keberanian mengemukakan pendapat & 3,7 & 3,8 \\
Ketrampilan menggunakan alat/media & 3,9 & 3,9 \\
Tekun dalam bekerja & 3,4 & 3,5 \\
Menggunakan waktu dengan efektif & 3,3 & 3,3 \\
Mampu bekerja sama & 3,6 & 3,7 \\
\multicolumn{1}{c}{ Rerata } & 3,5 & 3,6 \\
\hline
\end{tabular}

Berdasarkan tabel hasil observasi partisipasi siswa siklus II di atas, dapat dilihat bahwa dari aspek partisipasi siswa diperoleh data dengan rerata 3,5 maka dapat dikatakan partisipasi siswa menunjukkan pada sangat sering berpartisipasi dalam kegiatan pembelajaran.

\section{Refleksi (Reflecting)}

Refleksi pada siklus II ini dilakukan bersama guru kelas untuk melakukan penilaian selama proses pembelajaran Matematika dengan menggunakan pembelajaran matematika realistik. Dari hasil analisa data observasi dan partisipasi siswa dapat disimpulkan bahwa penerapan Pembelajaran Matematika Realistik dapat dilaksanakan dengan baik sesuai dengan langkah yang telah ditetapkan sebelumnya.

Hasil observasi terhadap aktivitas guru pada proses pembelajaran matematika realistik pada siklus II diperoleh hasil bahwa guru telah melaksanakan tahapan aktivitas sesuai dengan yang telah ditetapkan dalam lembar pengamatan siklus II, tahapan ini merupakan perbaikan dari siklus I.

Hasil belajar siswa berdasarkan hasil analisa data penelitian menunjukkan telah mencapai nilai KKM sebesar $\geq 6,5$ meningkat sejumlah 8 siswa, dari Siklus I jumlah siswa yang tuntas belajar adalah 19 siswa pada siklus II meningkat menjadi 32 siswa. Hal ini menunjukkan bahwa pembelajaran telah dapat dikatakan berhasil karena telah memenuhi kriteria keberhasilan yaitu $\geq 75 \%$ karena dalam siklus II ini sebanyak 32 siswa $(86,49 \%)$ dari keseluruhan siswa yaitu 37siswa sudah mencapai Kriteria Ketuntasan Minimal (KKM). Tindakan dalam penelitian ini dikatakan berhasil dan dihentikan pada siklus II karena telah memenuhi kriteria keberhasilan.

\section{Pembahasan}

Penelitian Tindakan Kelas dalam penelitian ini terdiri dari 2 siklus yang terbagi atas siklus I dan siklus II. Setiap siklus terdiri dari 2 kali pertemuan dan terdiri dari beberapa tahap, yaitu tahap perencanaan, tahap tindakan, tahap observasi, dan tahap refleksi. Pada siklus II tahap yang dilaksanakan adalah perbaikan pada siklus sebelumnya. Hasil yang diperoleh pada penelitian ini terdiri dari hasil data tes yang merupakan hasil belajar kognitif dan hasil belajar afektif. Hasil dari kedua siklus tersebut digunakan untuk mengetahui peningkatan hasil belajar Matematika dengan menggunakan Pembelajaran Matematika Realistik pada siswa kelas V. Selain dapat meningkatkan 


\section{$\pi$ (Phi)}

hasil belajar kognitif siswa, pendekatan Pembelajaran Matematika Realistik ini juga dapat meningkatkan kualitas proses pembelajaran berupa peningkatan partisipasi siswa yang berlangsung di dalam kelas selama pembelajaran berlangsung.

\section{Pendekatan}

Pembelajaran

Matematika Realistik pada siklus I dan II, diterapkan pada materi masalah-masalah nyata dari kehidupan sehari-hari seperti suhu di dalam kulkas dan juga membagikan permen yang digunakan sebagai bahan dan alat peraga dalam proses pembelajaran matematika realistik. Penggunaan benda dan alat yang biasa digunakan sehari-hari disekitar kita untuk menjelaskan bahwa mata pelajaran matematika sangat erat kaitannya dengan kehidupan sehari-hari. Benda-benda seperti kancing baju dan kartu bilangan yang berwarna-warni dapat digunakan sebagai alat peraga. Alat peraga yang berasal dari sekitar siswa dipergunakan sebagai strategi mendekatkan siswa dengan materi sehingga siswa menjadi lebih tertarik. Dalam penggunaan alat peraga secara bersamaan siswa bisa menerima/menyerap materi yang sedang diajarkan oleh guru. Hal ini ditunjukkan dengan meningkatnya hasil belajar materi operasi hitung campuran bilangan bulat . Hal tersebut senada dengan pendapat Hadi dalam (Aisyah dkk, 2007) bahwa melalui Pembelajaran Matematika Realitstik siswa menjadi lebih tertarik dan senang belajar matematika serta menunjukkan peningkatan hasil belajar yang cukup memuaskan.

Guru memberikan waktu kepada siswa untuk melakukan diskusi untuk menemukan konsep operasi hitung campuran bilangan bulat. Kegiatan tersebut mendorong adanya interaksi antar teman dalam proses pembelajaran, hal ini memberi kesempatan siswa untuk bersosialisasi dengan menghargai perbedaan pendapat dan berlatih untuk bekerja sama. Kegiatan diskusi dapat dilaksanakan semakin sering terbukti dapat meningkatkan interaksi serta kerja sama. Seringnya aktivitas diskusi menunjukkan adanya peningkatan partisipasi siswa pada setiap siklus, terjadinya peningkatan hasil belajar siswa tersebut merupakan hasil dari pembelajaran melalui PMR yang secara umum berjalan .dengan baik seperti yang dilihat dari hasil pengamatan pada saat pembelajaran berlangsung.

Partisipasi aktif siswa dalam aktivitas pembelajaran atau aktivitas untuk menemukan sendiri konsep matematika akan mendorong siswa untuk lebih senang dan semangat mengikuti proses pembelajaran matematika. Hal tersebut sesuai dengan pendapat Sugihartono (20070 bahwa pengamatan sangat penting dan menjadi dasar dalam menuntun proses belajar oleh karena itu dalam belajar diupayakan siswa harus mengalami sendiri dan terlibat langsung secara realistik dengan obyek yang dipelajarinya.

Hasil pengamatan yang dilakukan oleh peneliti sebagai observer diperoleh hasil bahwa siswa terlihat lebih aktif dari sebelum dilakukan tindakan. Perubahan sikap ini dikarenakan pada pembelajaran Matematika Realistik guru memberikan pengalaman langsung kepada siswa untuk melaksanakan berbagai kegiatan yang menuntut siswa untuk aktif secara kognitif, afektif dan psikomotor. Untuk kemampuan kognitifnya siswa diberi tugas untuk menuliskan hasil dari penggunaan alat peraga. Hal tersebut dilakukan melalui diskusi kelompok. Setelah itu, guru memberikan kesempatan kepada masingmasing kelompok untuk mempresentasikan hasil diskusinya di depan kelas. Untuk mengulangi materi yang telah dipelajari guru memancing siswa dengan pertanyaan- 
pertanyaan singkat sehingga siswa mampu menyimpulkan sendiri materi yang telah dipelajarinya dan mampu membangkitkan motivasi siswa dalam belajar.

Berdasarkan beberapa paparan di atas disimpulkan bahwa penelitian tindakan kelas yang dilakukan dapat meningkatkan hasil belajar siswa kelas V SDN 144/IX Solok melalui pendekatan Matematika Realistik. Hal tersebut dibuktikan dengan adanya perubahanperubahan yang terjadi pada hasil belajar siswa. Penelitian ini sudah mencapai kriteria keberhasilan yang ditentukan, yaitu 75\% dari jumlah seluruh siswa sudah mencapai minimal predikat baik,sehingga penelitian ini dikatakan berhasil dan dihentikan pada siklus II.

\section{KESIMPULAN DAN SARAN Kesimpulan}

Berdasarkan hasil penelitian yang telah dilaksanakan, maka dapat disimpulkan bahwa hasil belajar matematika siswa kelas $\mathrm{V}$ melalui Pembelajaran Matematika Realistik mengalami peningkatan. Pembelajaran siklus I dan II, guru menggunakan masalah kontekstual yang berkaitan dengan materi untuk memulai pembelajaran, siswa menggunakan alat peraga yang berasal dari lingkungan sekitar siswa, mendiskusikan hasil dari penggunaan alat peraga, menemukan konsep berdasarkan hasil diskusi. Memperkenalkan prosedur baku untuk menyelesaikan masalah menggunakan logika dan mengaitkan konsep dalam materi operasi hitung campuran bilangan bulat. Sebelum siswa menyelesaikan masalah maka terlebih dahulu siswa telah telibat langsung menggunakan alat peraga, melakukan pengamatan dan diskusi kelompok dalam menemukan konsep sehingga selain membuat siswa lebih aktif maka konsep yang dipelajari akan lebih mudah diingat siswa.

Peningkatan kualitas proses pembelajaran tersebut sejalan dengan peningkatan hasil tes yang diperoleh. Hasil belajar kognitif mengalami peningkatan $35,14 \%$ yaitu dari siklus I sebesar 51,35\% (19 siswa) menjadi 86,49\% (32 siswa) pada siklus II. Pada tahap siklus II persentase keberhasilannya mencapai $\geq$ 75\% sehingga siklus ini dihentikan.

Berdasarkan hasil observasi parisipasi siswa dalam pembeajaran siklus I, dilihat dari beberapa aspek sikap siswa yang terdiri dari: 1) perhatian siswa terhadap pelajaran; 2) partisipasi dalam kelompok; 3) kemampuan berkomunikasi 4) keberanian mengemukakan pendapat; 5) Ketrampilan menggunakan alat/media; 6) Tekun dalam bekerja; 7) Menggunakan waktu dengan efektif dan 8) Mampu bekerja sama, diperoleh hasil pengamatan partisipasi siswa pada mata pelajaran matematika mencapai $74,39 \%$ (dari 37 siswa) sedangkan pada siklus II diperoleh hasil rata-rata sebesar $88,56 \%$ (dari 37 siswa). Dari analisa data hasil penelitian telah dibuktikan bahwa prestasi belajar siswa meningkat dan telah mencapai indikator keberhasilan yang ditetapkan yaitu $75 \%$ dari 37 siswa telah menunjukkan keaktifan dalam pelajaran berdasakan lembar observasi yang telah dibuat.

\section{Saran}

Berdasarkan hasil penelitian yang telah dilaksanakan, dapat sampaikan beberapa saran sebagai berikut :

1. Bagi guru Matematika, pembelajaran matematika realistik merupakan salah satu alternatif pendekatan dalam pembelajaran matematika yang dapat digunakan sebagai alternatif untuk mengajarkan materi khususnya operasi hitung campuran bilangan bulat.

2. Bagi sekolah, pendekatan PMR perlu 


\section{$\pi$ (Phi)}

dikembangkan dan didukung dengan penyediaan berbagai sarana dan prasarana yang menunjang terciptanya pembelajaran

\section{DAFTAR PUSTAKA}

Aisyah, N. dkk. (2007). Pengembangan Pembelajaran Matematika SD. Jakarta: Depdiknas Dirjen Dikti Direktorat Ketenagaan.

Anderson, L. W. \& Krathwohl, D. (2015). Kerangka Landasan Untuk Pembelajaran, Pengajaran, dan Asesmen. Yogyakarta: Pustaka Pelajar.

Arikunto, S. (2007). Penelitian Tindakan Kelas. Jakarta: Bumi Aksara.

Arikunto, S. (2006). Metode Penelitian Kualitatif. Jakarta: Bumi Aksara

Prihandoko, A. C. (2006). Memahami konsep matematika secara benar dan menyajikannya dengan menarik. Jakarta: Depdiknas Dirjen Dikti Direktorat Ketenagaan.

Sanjaya, W. (2011). Penelitian Tindakan Kelas. Jakarta: Kencana.

Subarinah, S. (2006). Inovasi Pembelajaran Matematika SD. Depdiknas: Jakarta.

Sudijono, A. (2010). Pengantar Statistik Pendidikan. Jakarta: PT Rajagrafindo Persada.

Sudjana, N. (2006). Penilaian Hasil Proses Belajar Mengajar. Bandung: PT Remaja Rosda Karya.

Sugihartono, dkk. (2007). Psikologi Pendidikan. Yogyakarta: UNY Press.

Sugiyono. (2012). Metode Penelitian Kuantitatif Kualitatif dan R\&D. Bandung: Alfabeta.

Suharjo. (2006). Mengenal Pendidikan Sekolah Dasar: Teori dan Praktek. Jakarta: Depdiknas Dirjen Dikti Direktorat Ketenagaan.

Tarigan, D. (2006). Pembelajaran Matematika Realistik. Jakarta: Depdiknas Dirjen Dikti Direktorat yang optimal dan efektif sehingga kualitas prestasi belajar Matematika dan kulitas sekolah dapat terus meningkat.

Ketenagaan.

Widoyoko, E. P. (2009). Evaluasi Program Pembelajaran. Yogyakarta: Pustaka Pelajar. 